\title{
Atípusos aortacoarctatiók sebészi kezelésének hosszú távú eredményei
}

\author{
Dzsinich Csaba dr. ${ }^{1}$ - Entz László dr. ${ }^{2}$ - Berek Péter dr. ${ }^{1}$ - Vallus Gábor dr. ${ }^{1}$ \\ Barta László dr. ${ }^{1}$ - Nagy Gabriella dr. ${ }^{1}$ - Nyiri Gabriella dr. ${ }^{1}$ \\ ${ }^{1}$ HM Egészségügyi Központ, Szív-, Ér- és Mellkas-sebészeti Osztály, Budapest \\ ${ }^{2}$ Semmelweis Egyetem, Általános Orvostudományi Kar, Városmajori Szív- és Érgyógyászati Klinika, \\ Érsebészeti Tanszék, Budapest
}

\begin{abstract}
Bevezetés: Az aortacoarctatio a leggyakoribb congenitalis cardiovascularis elváltozások egyike, azok 5-8\%-ában fordul elő. Típusos előfordulási helye az isthmicus szakasz. Atípusos helyen kialakuló coarctatio az esetek mintegy $1 \%$-ában fordul elő és többnyire súlyos hypertoniával szövődik. Célkitüzés: A szerzők célul tűzték ki a kórkép sebészi kezelési lehetôségeinek és azok hosszú távú eredményeinek ismertetését 27 beteg mútéti kezelésével szerzett tapasztalataik alapján. Módszer: A 35 évet felölelő utánkövetés során a diagnosztika és a kezelési módszerek változtak. Napjainkban a morfológiai diagnózis legáltalánosabb módszerei a komputertomográfiás angiográfia és a mágneses rezonanciás angiográfia. Az aortarekonstrukció lehetőségei az endovascularis technikák bevezetésével gazdagodtak, de atípusos aortacoartatio esetében a szerzók ma is túlnyomóan változatos sebészi megoldásokat alkalmaznak. Eredmények: A mútétek után nem veszítettek el beteget. A hypertonia minden esetben jelentősen csökkent. Gyermekkorban operált esetekben a növekedés okozta testméretváltozások 3 esetben újabb rekonstrukciós mútétet indokoltak. Következtetések: Az atípusos aortacoarctatio individuális sebészi módszerekkel eredményesen kezelhető. Gyermekkorban operált esetekben a testméret-növekedés a rekonstruált aortaszakasz revízióját teheti szükségessé. Orv. Hetil., 2016, $157(26), 1043-1051$
\end{abstract}

Kulcsszavak: atípusos aortacoarctatio, sebészi kezelés, késői eredmények

\section{Surgical treatment of atypical aortic coarctation. Long-term results}

Introduction: Aortic coarctation is a frequent congenital cardiovascular disorder representing $5-8 \%$ of all cases. It is typically localized in the isthmic region. However, in about $1 \%$ of cases coarctation may develop in atypical sites of the aorta and it is frequently complicated with severe hypertension. Aim: The aim of the authors was to present diagnostic and surgical methods used in 27 patients with atypical aortic coarctation during the last 35 years with special interest on long-term results. Method: There was a great advance in diagnostic and surgical treatment methods during the time period analyzed in this study. Nowadays morphologic diagnosis is most commonly obtained using computed tomography angiography and magnetic resonance angiography. Some cases were treated with endovascular techniques, but the authors used also a wide variety of surgical approaches in these patients with atypical aortic coarctation. Results: No patient died after surgery and hypertension was reduced in all patients, too. Reintervention was necessary in patients operated in childhood due to change of body measures. Conclusions: Atypical aortic coarctation can be treated surgically with good early and late outcomes. Somatic growth of children may indicate surgical revision.

Keywords: atypical aortic coarctation, surgical treatment, long-term results

Dzsinich, Cs., Entz, L., Berek, P., Vallus, G., Barta, L., Nagy, G., Nyiri, G. [Surgical treatment of atypical aortic coarctation. Long-term results]. Orv. Hetil., 2016, 157(26), 1043-1051.

(Beérkezett: 2015. október 15.; elfogadva: 2016. április 10.) 


\section{Rövidítések}

CTA = komputertomográfiás angiográfia; DSA = digitális szubtrakciós angiográfia; MRA = mágneses rezonanciás angiográfia; PTFE $=$ politetra-fluor-etilén

A típusos aortacoarctatio a congenitalis cardiovascularis elváltozások egyik leggyakoribb változata, azok mintegy 5-8\%-át képviseli és gyakorta más szívelváltozásokkal társul. Turner-szindrómában szenvedő betegekben mintegy $5 \%$-ban fordul elő.

A bal kamra számára keringési akadályt jelentő szúkület a subvalvularis, valvularis és supravalvularis szúkülettôl kezdve az aorta bármely szakaszán kialakulhat. Az aortaíven, az aorta descendensen és abdominalison jelentkező szúkületek, az atípusos aortacoarctatiók az úgynevezett aortaisthmus szintjén kialakuló típusos coarctatiók 1-2\%-át teszik ki. Egyes megjelenési formái nem feltétlenül congenitalisak, azokat Takayasu-szindróma vagy más betegség részjelenségének vélik. A szükület mértékétől függő következményes hypertonia, az állandó cardialis túlterhelés a beteg életkilátásait jelentősen rontja. A kezeletlen betegek átlagélettartama mintegy 35 év.

Atípusos aortacoarctatio miatt 1980 óta 27 beteget operáltunk intézeteinkben. A változatos sebészi megoldások korai és késői eredményeit tekintjük át dolgozatunkban.

\section{Módszer}

1980 és 2015 között 27 beteget operáltunk atípusos aortacoarctatio miatt. Betegeink között 8 nó és 19 férfi volt. Életkoruk 2 és 52 év közötti, átlagosan 16 év volt. A 27 betegből mindössze 4 volt felnőttkorú, 12 gyermekkorú és 9 serdülő. Utóbbiakban véglegesnek tekinthető testmérettel mindössze 6 beteg rendelkezett. Vezetô tünet valamennyi esetben a magas vérnyomás volt. Valamennyi beteg, egy kivételével, súlyos hypertoniával került kivizsgálásra. A hypertoniás betegek szisztolés vérnyomásértékei 160 és 280, a diasztolés értékei 100 és $145 \mathrm{Hgmm}$ között, átlagosan 185, illetve $122 \mathrm{Hgmm}$ közötti volt. Intractabilis hypertoniát, jelentős cardiomegaliát 4 , cardialis decompensatiót 2 betegnél észleltünk. Postprandialis fájdalma, dysbasiája egyik betegnek sem volt. Egy 26 éves nőbeteg a jobb láb 5. ujján kis, microembolisatio okozta gangraenával került felvételre (1. táblázat). Fizikális jelként parasternalis zörejt egy esetben, parascapularist 5, epigastrialist 26 és köldöktáji zörejt 7 betegnél regisztráltunk. Az alsó végtagi bokatáji pulzáció egyetlen esetben sem volt tapintható, a femoralis pulzáció 6 betegnél volt sejthető. A felső és alsó végtagok közötti nyomásgradiens 25 és $100 \mathrm{Hgmm}$ között, átlagosan $44 \mathrm{Hgmm}$ volt. A betegek laboratóriumi értékei aktív gyulladásos folyamatra egyik esetben sem utaltak, azonban 4 betegünk a potenciális gyulladásos háttér miatt szteroidkezelésben részesült. A lobos háttér gya-
1. táblázat Atípusos aortacoarctatio miatt operált betegek adatai

\begin{tabular}{ll}
\hline Betegszám 27 & 19 férfi, 8 nö \\
\hline Életkor: 2-52 év & Átlagosan 16 év \\
\hline Hypertoniás 26 & Normotenzív 1 \\
\hline Hypertonia mértéke & $160-280 \mathrm{Hgmm}$, \\
Szisztolés vérnyomás & átlagosan $185 \mathrm{Hgmm}$ \\
Diasztolés vérnyomás & $\begin{array}{l}100-145 \mathrm{Hgmm}, \\
\text { átlagosan } 122 \mathrm{Hgmm}\end{array}$ \\
\hline Terápiarezisztens hypertonia & 4 beteg \\
\hline Cor bovinum, szívelégtelenség & 4 \\
\hline Globális vesefunkció-zavar & 0 \\
\hline Postprandialis fájdalom & 0 \\
\hline Dysbasia & 0 \\
\hline Lábujjgangraena & 1 \\
\hline
\end{tabular}

núját az aortafal morfológiai elváltozásai sejtették. A globális vesefunkció vizsgálata minden betegnél a normálértékeket mutatta.

A képalkotó eljárások az elmúlt 35 év alatt jelentősen megváltoztak. Az 1980-90-es években a hagyományos és digitális szubtrakciós angiográfia (DSA), majd fokozatosan a CT-angiográfia (CTA) került előtérbe és szolgáltatta a képi diagnózist. Egy esetben az aortaív atípusos szúkülete Kommerell-diverticulummal és arteria (a.) lusoriával szövődött. A bal a. subclavia alatt súlyos, csaknem interruptiót okozó aortaív-szúkület a két kar között $90 \mathrm{Hgmm}$ gradienst okozott. A jobb a. subclavia a coarctatio alatti aortaszakaszból eredt (1. ábra). Az aorta

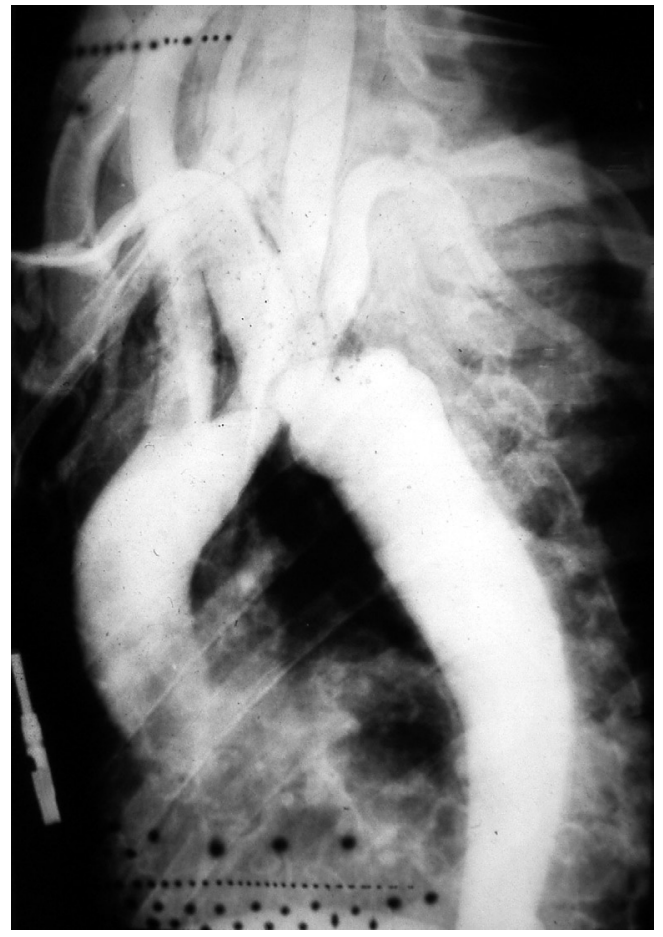

l. ábra Atípusos aortacoarctatio az aortaíven a distalis aortaívből Kommerell-diverticulummal induló jobb arteria subclaviával 


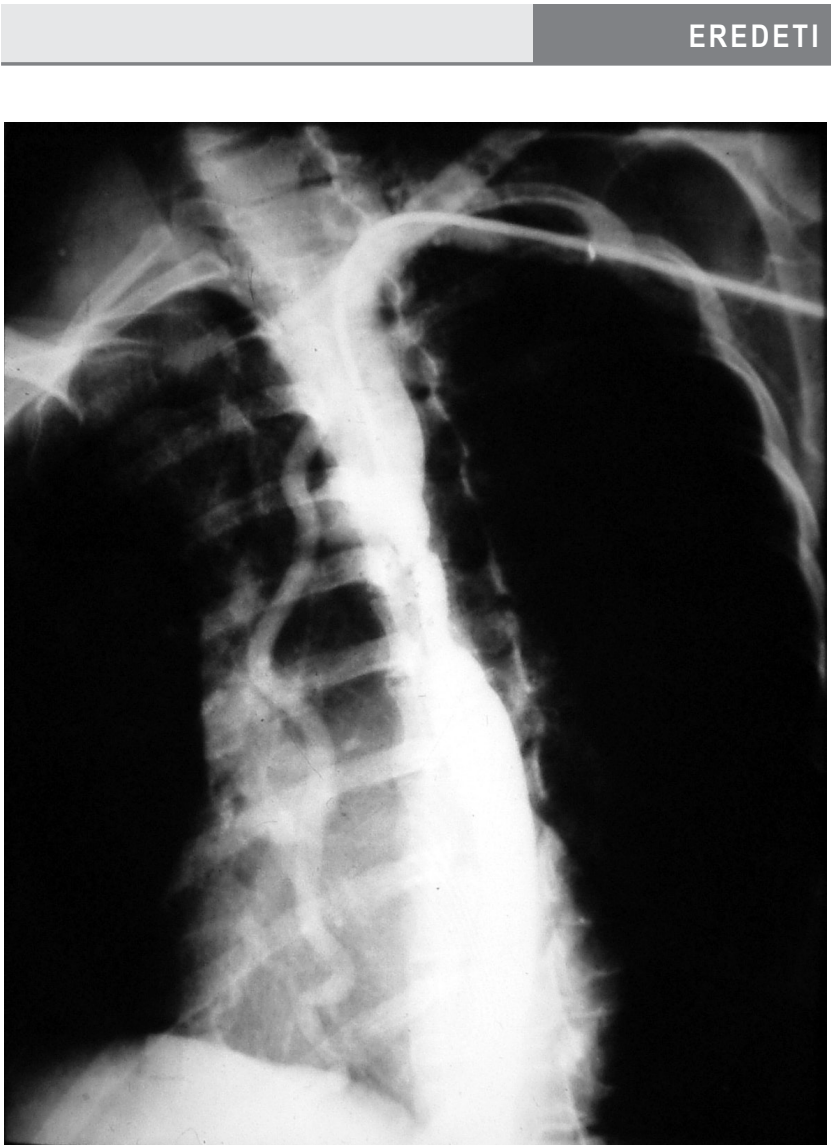

2. ábra

Az aorta descendens proximalis szakaszának hosszú szakaszú coarctatiója jól látható kollaterális keringést biztosító a. mammaria tágulattal 52 éves férfi betegünk esetében

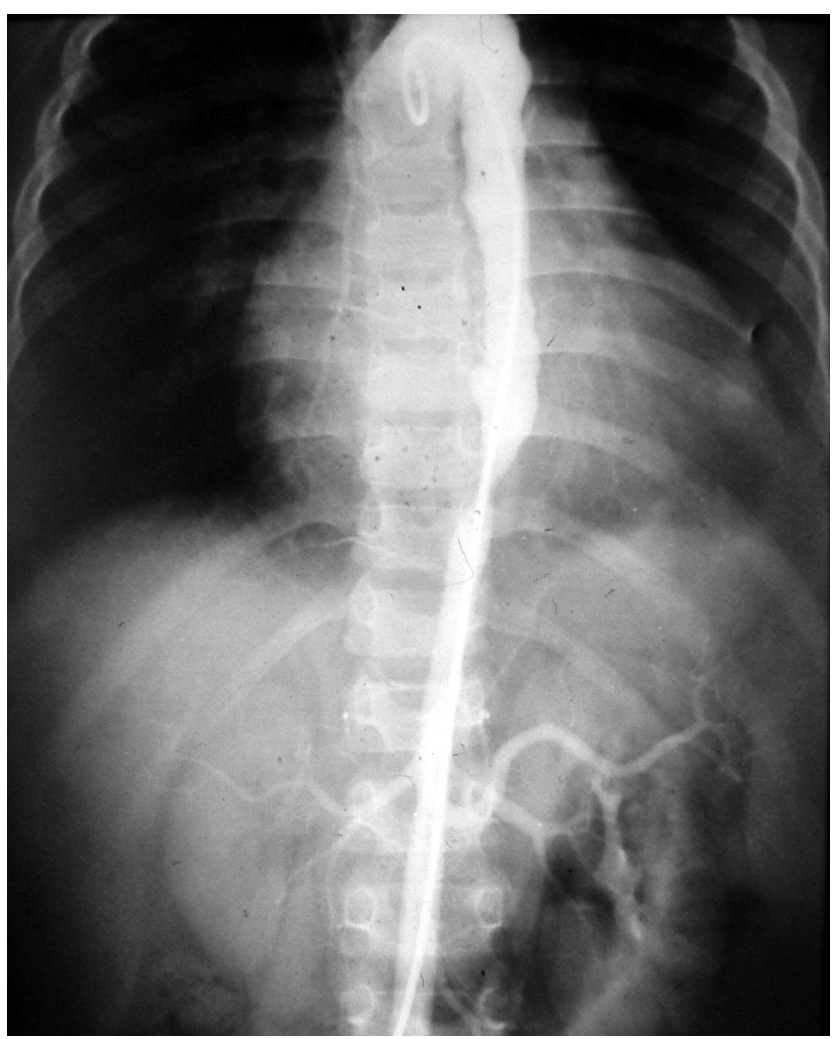

3. ábra

Az aorta descendens középső szakaszán kialakult coarctatio. Az aorta egyenetlen kontúrja aortitis morfológiai jeleit mutatja egy 6 éves gyermekben, aki jelentős cardiomegaliával és intractabilis hypertoniával került mútétre

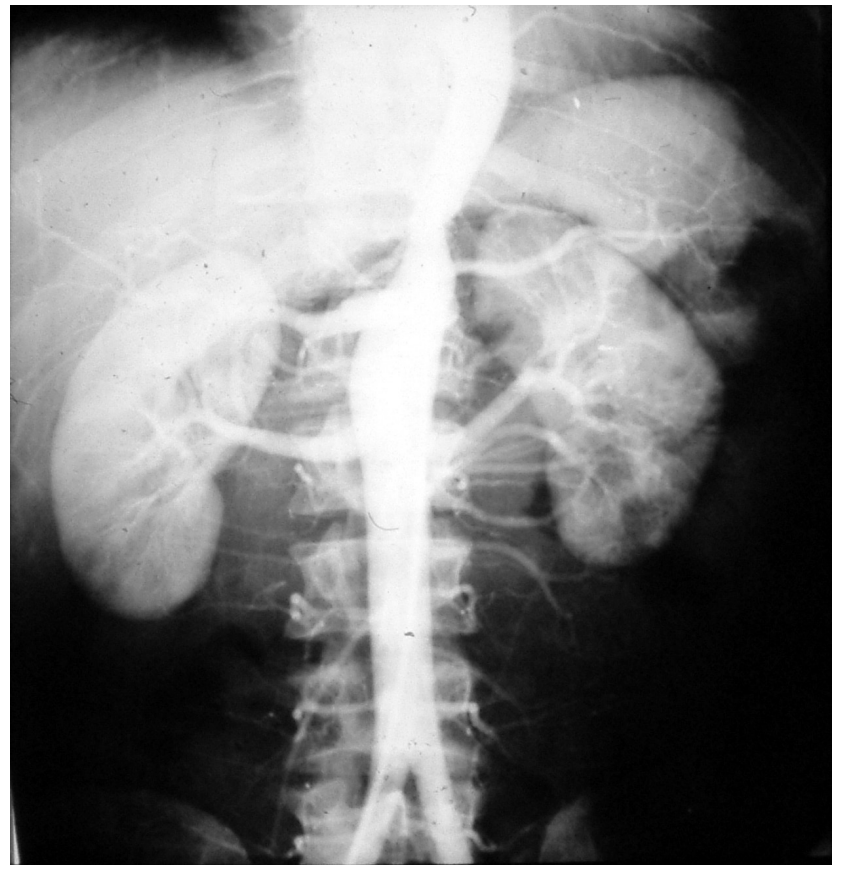

4. ábra

24 éves férfi angiogramja. A beteg kezelhetetlen hypertoniával a rekeszcsatorna szintjén kialakult coarctatio miatt került mútétre 35 évvel ezelőtt. Dacron foltplasztikával oldottuk meg

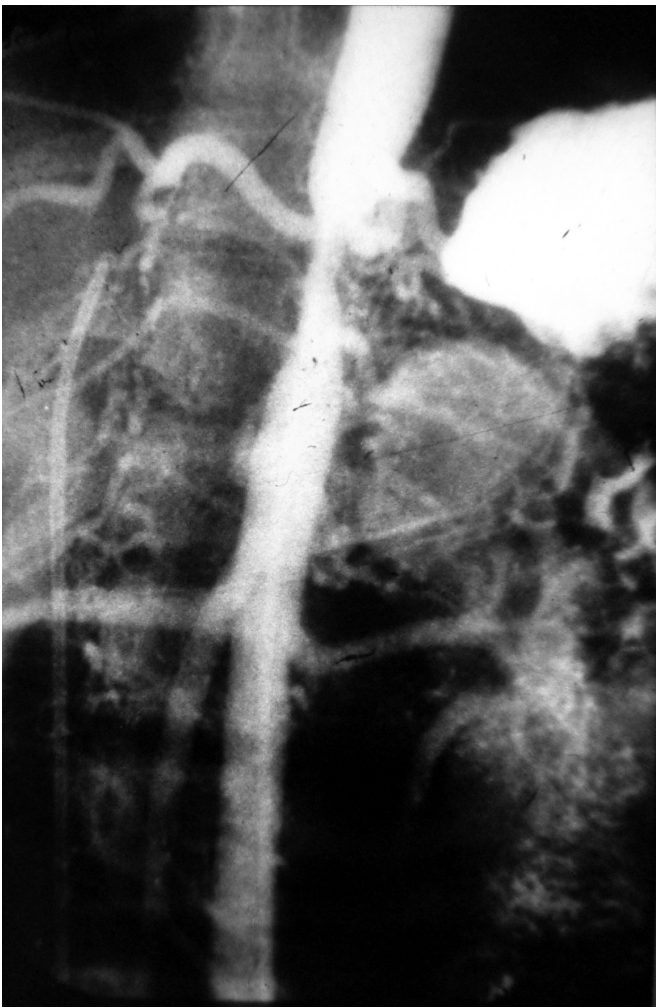

5. ábra

14 éves lány hypertoniáját intervisceralis, suprarenalis aortacoarctatio okozta

descendens középső szakaszán 7 esetben (2. ábra), az alsó szakaszán 5 esetben (3. ábra), a thoracoabdominalis átmenetben 4 esetben (4. ábra), a visceralis aortaszegmentumon 7 esetben (5. ábra) és a subrenalis aortán 


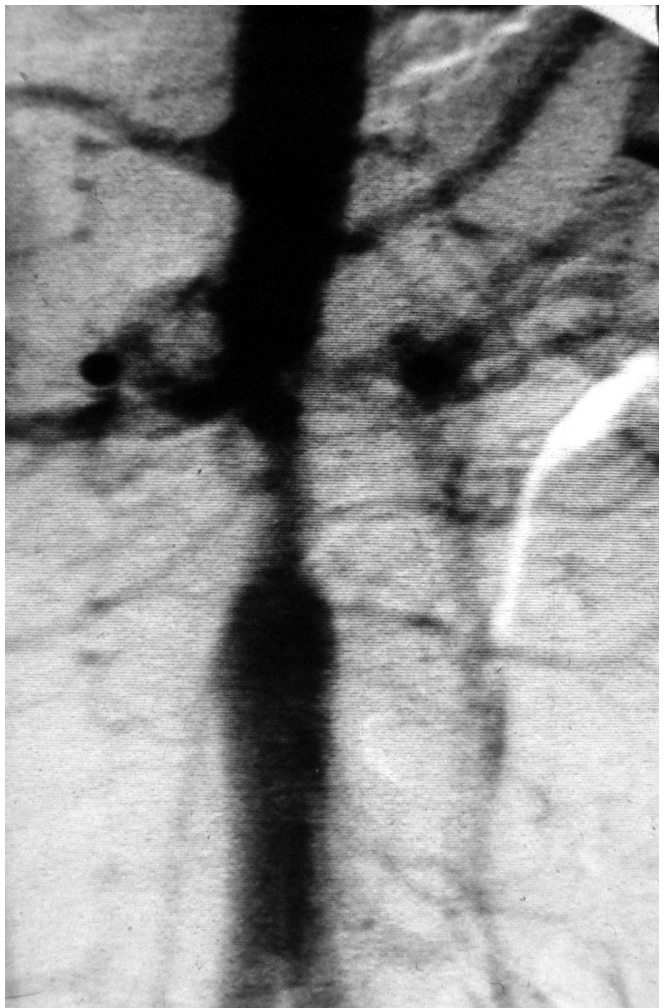

6. ábra 24 éves nő mérsékelt hypertoniával aorta abdominalis coarctatió-
val került mútétre

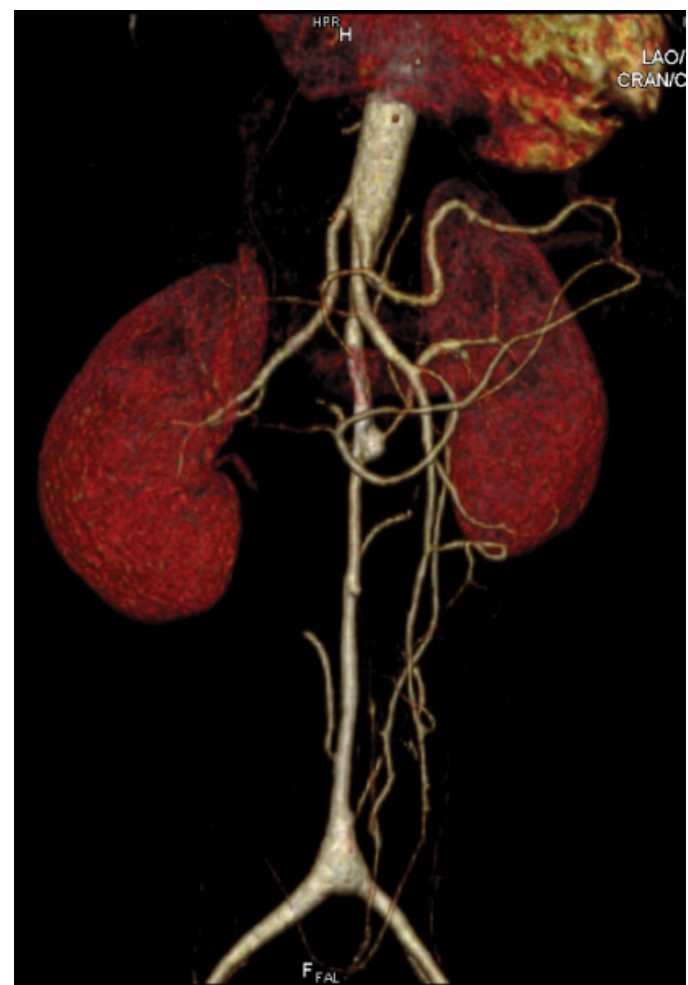

7. ábra

| Fiatal nőbeteg aorta abdominalis hosszú szakaszú coarctatiója

2 esetben (6. és 7. ábra) észleltük az elváltozást. A teljes aorta descendenst és abdominalist érintő aorta angustát egy esetben észleltünk (8. ábra). Az atípusos aortacoarc-

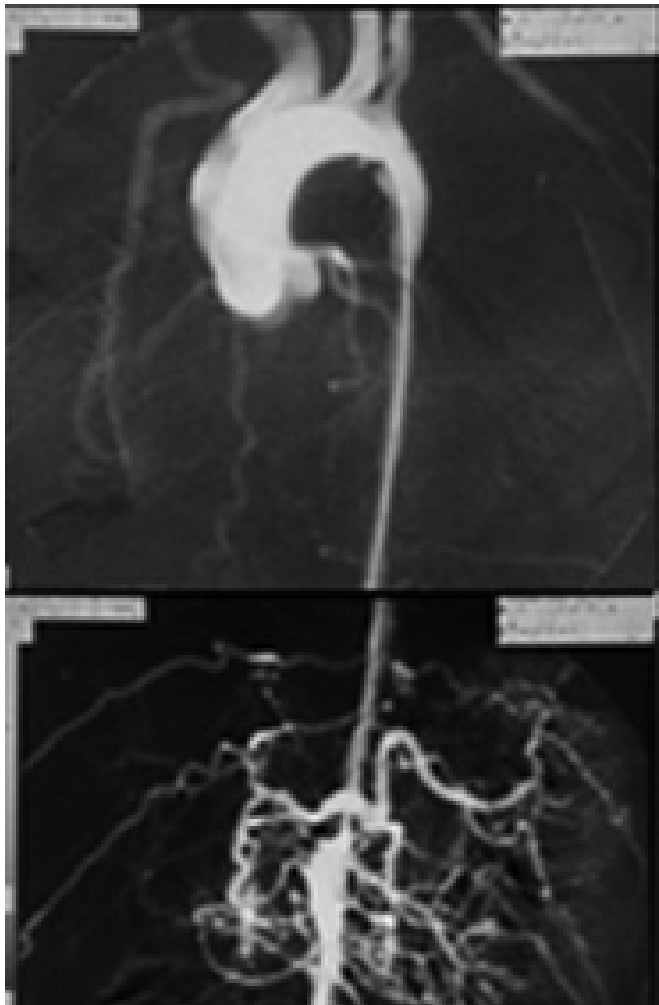

8. ábra

12 éves fiú aortogramja. Aorta angusta képe. Az aorta átmérője $3 \mathrm{~mm}$. A normálméretű a. mesenterica superior dús kollaterális artériákból táplálkozik. A beteg 2 éves korában az isthmicus aorta foltplasztikáján esett át

tatio diagnózisát szolgáltató képalkotó eljárásokat és az elváltozás elhelyezkedését, kiterjedését a 2. táblázatban foglaltuk össze.

A subdiaphragmaticus atípusos aortacoarctatiók morfológiai változatai az alábbiak:

- supravisceralis,

- intervisceralis (a truncus coeliacus és az a. mesenterica superior között),

2. táblázat $\mid$ Az atípusos aortacoarctatio képalkotó vizsgálata és lokalizációja

\begin{tabular}{llll}
\hline DSA 18 & CTA 9 & Mindkettő 7 \\
\hline A coarctatio elhelyezkedése és morfológiája & $\begin{array}{l}\text { Rövid } \\
\text { szakasz }\end{array}$ & $\begin{array}{l}\text { Hosszú } \\
\text { szakasz }\end{array}$ & $\begin{array}{l}\text { Egyéb } \\
\text { malformatio }\end{array}$ \\
\hline Aortaíven & 1 & & $\begin{array}{l}\text { Arteria } \\
\text { lusoria }\end{array}$ \\
Aorta descendens & 5 & 2 & \\
Aorta angusta & & 1 & \\
Distalis aorta descendens & 5 & & Renalis \\
Thoracoabdominalis aorta & 4 & 3 & aneurysma \\
Visceralis aorta & 4 & 1 & \\
Subrenalis aorta & 1 & & \\
\hline
\end{tabular}

$\mathrm{CTA}=$ komputertomográfiás angiográfia; DSA = digitális szubtrakciós angiográfia. 
- suprarenalis (az a. mesenterica superior és a renalis szájadékok között),

- infrarenalis,

- multivisceralis érintettséggel járó aortacoarctatio.

A mútéti javallat alapját a morfológiai elváltozás mellett a súlyos hypertonia képezte. Utóbbi okát az aortastenosis következtében kialakult áramlási rezisztencia, illetve a filtrációs nyomás fenntartása érdekében fellépö renovascularis mechanizmusú hypertonia kialakulásában láttuk. Tapasztalatunk szerint minél közelebb helyezkedett el az aortacoarctatio a veseartériák szájadékához, annál nehezebben kezelhető hypertonia alakult ki, amelynek befolyásolásában a konvertálóenzim-bénító szerek fokozott hatékonysága szolgáltatott indirekt bizonyítékot.

$\mathrm{Az}$ alkalmazott mútéti megoldásokat a 3. táblázatban foglaltuk össze. Az atípusos aortacoarctatio mütéti megközelítése 14 esetben thoracotomia, 8 esetben thoracoabdominalis, 1 esetben thoracalis és szeparált abdominalis-extraperitonealis és 4 esetben abdominalis feltárás révén vált lehetségessé.

A mûtéti megoldásokat befolyásoló tényezők sokrétűek. Időzítés tekintetében - amennyiben a klinikai helyzet lehetővé teszi - célszerű várni a testméretek növekedésére, azért, hogy lehetőleg a végleges megoldást jelentő méretü grafttal végezhessük a beavatkozást. Négy esetben - jól befolyásolható hypertonia esetén - a cardialis és vesefunkciók rendszeres ellenőrzése mellett 3-5 évet vártunk a gyermek növekedésére, majd a szűkült szegmentumot 10-12 mm átmérőjü grafttal hidaltuk át. Ez a méretü érprotézis hosszú távon biztosítja a distalis keringést. A bypassmegoldás és ívelt graft behelyezése lehetőséget ad a testméretváltozások követésére, nem sérti a kialakult kollaterális keringést és elkerüli a szúkuült szakaszon jelen lévő muralis kalcifikációt. A mütétek során zéró porozitású Dacron és PTFE-anyagú érprotéziseket használtunk (8. és 9. ábra). Egy férfi és egy nőbetegünk-

3. táblázat $\mid$ Az atípusos aortacoarctatio miatt végzett mútéti beavatkozások

Jobb subclavio-croticus transzpozíció + distalis aortaív1 foltplasztika

Ívelt bypass az isthmicus aortától az aortabifurcatióig +

a renalis és visceralis artériák replantációjával

Ívelt aortoaorticus bypass az aorta descendens területén 6

Aortoaorticus graft interpozíciója az aorta descendens középső 1 szakaszán

Aorta descendens, aorta abdominalis ívelt bypass + renalis $\quad 1$ replantáció

$\mathrm{Az}$ aorta descendens foltplasztikája

A thoracoabdominalis aortaszakasz foltplasztikája

A visceralis aortaszegmentum foltplasztikája

A visceralis aortaszegmentum + a. renalis foltplasztikája

Hepatorenalis és splenorenalis bypass

Subrenalis aorta foltplasztikája

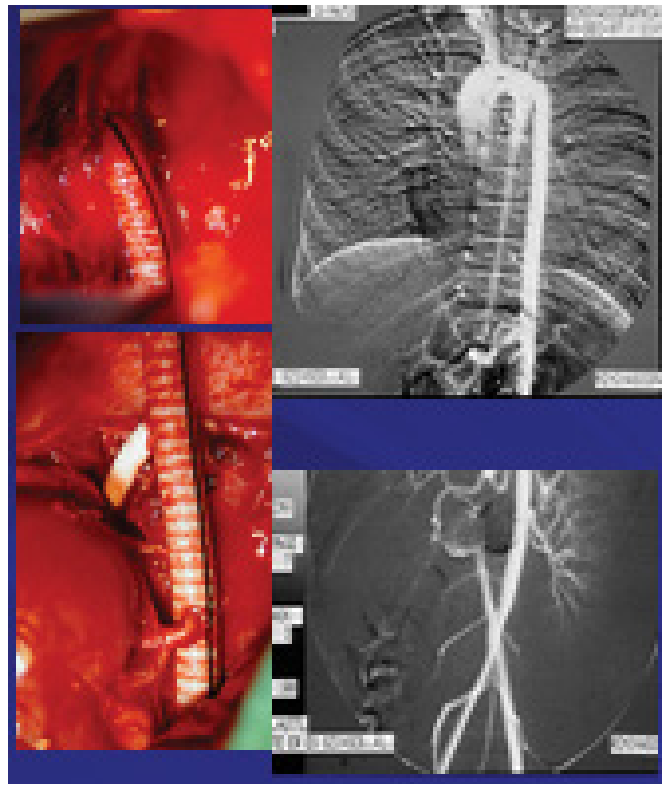

9. ábra

Az aorta angusta (8. ábra) mútéti megoldása thoracoabdominalis Dacron graft beültetésével és a zsigeri ágak implantációjával 15 évvel a mütét után

ben a rövid szakaszú suprarenalis szúkület megoldására jobb oldalon hepatorenalis és a bal oldalon splenorenalis áthidalást alkalmaztunk. Egy nőbetegünkben a supravisceralis membránszerü coarctatio peremén thromboticus felrakódást találtunk, ami a lábujjgangraenához vezető microembolisatio forrása volt. A carina körkörös kimetszése és foltplasztika volt a mütéti beavatkozás (10. ábra).

\section{Eredmények}

\section{Korai eredmények}

Korai szövődményünk nem volt. Betegeink eseménytelenül gyógyultak. Minden betegnél megjelentek a bokatáji pulzusok, a korábbi gradiens 10-20 Hgmm közé csökkent. A hypertonia kivétel nélkül jelentősen mérséklődött, egy beteg nem igényelt gyógyszeres kezelést, a többiek monoterápiával voltak egyensúlyban tarthatók. A cardialis túlterhelés minden esetben napok alatt látványosan megszűnt.

\section{Késöi eredmények}

Betegeinket 4 és 35 év között, átlagosan 16 évig követtük. Valamennyi betegünk elérhető volt, a hosszú utánkövetés ellenére beteget nem vesztettünk el. Késői szövődmény 6 betegnél jelentkezett.

\section{Első és második beteg}

Két nőbetegnél észleltünk arteritisre utaló progressziót, amit a supraaorticus ágakon megjelenő obliteratio támasztott alá. Egyikük, a 26 éves korban végzett supradi- 


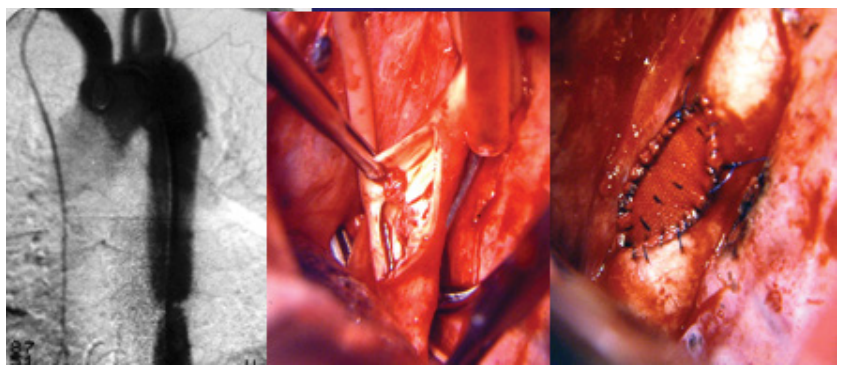

10. ábra

Rövid szakaszú aorta descendens coarctatio megoldása folt plasztikával. A carinán jól látható thromboticus appositio volt a perifériás embolisatio forrása

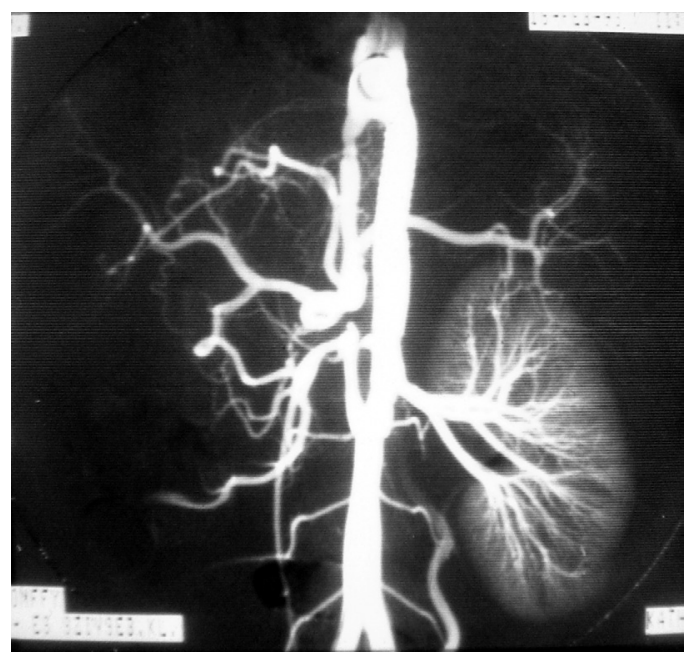

11. ábra

A mellkasi aortáról a hasi aortára vezetett Dacron bypass, amely be a renalis artériákat beültettük. Control DSA 30 évvel a primer műtét után és 20 évvel a graft foltplasztikáját követően (a 3. ábrán látható atípusos aortacoarctatio mútéti megoldása)

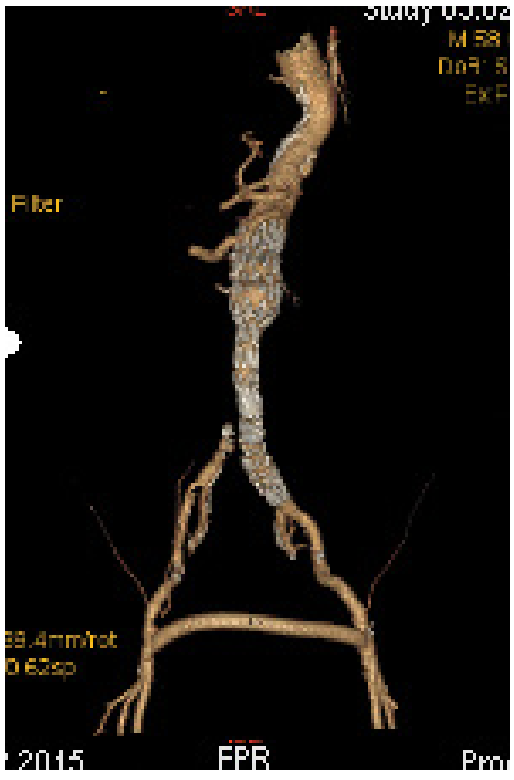

12. ábra

35 évvel korábban végzett thoracoabdominalis aortacoarctatio (4. ábra) miatt foltplasztika és egy évvel korábban rupturált hasi aorta miatt végzett monolimb stent gaft implantációja és crossover bypass 3D CTA-képe aphragmaticus carina kimetszése és aorta-foltplasztika után 24 évvel, arteria renalis stenosisa miatt kialakult zsugorvese állapotában került kivizsgálásra. Renalis insufficientia miatt dialízis vált szükségessé. Egyúttal a bal a. subclavia centrális szakaszának elzáródását állapítottuk meg. Steal-jelenség és felső végtagi panaszok miatt a bal arteria subclaviát a bal carotis communisba transzponáltuk.

A másik nőbeteg 16 éves korában suprarenalis rövid szakaszú coarctatio miatt splenorenalis, illetve hepatorenalis anastomosis kialakítása után 20 évvel jelentkezett ellenőrzésre, amelynek során a bal arteria subclavia elzáródását észleltük, ami revascularisatiót klinikai panaszok hiányában nem igényelt.

\section{Harmadik beteg}

Egy nőbetegben 12 éves korában az aorta descendens középső szakaszán mintegy $10 \mathrm{~cm}$-es graftinterpositiót végeztünk. 14 évvel később a beteg $45 \mathrm{~cm}$-rel magasabb testalkattal, tompa mellkasi fájdalommal, bal oldali renalis és alsó végtagi emboliával jelentkezett. CTA derített fényt az aortainterpositum mindkét anastomosisának leszakadása következtében kialakult, $80 \mathrm{~mm}$ átmérőjü álaneurysma kialakulására, amelyben a graft szabadon állt friss alvadékkal körülvéve, ami az embolisatio forrását képezte. Újabb thoracotomia során az aneurysma üregéből a thrombust és a leszakadt graftot eltávolítottuk, majd az aortát $18 \mathrm{~mm}$ átmérôjü Dacron graftinterpositummal állítottuk helyre. A klinikailag nem jelentős renalis és alsó végtagi embolisatio beavatkozást nem igényelt.

\section{Negyedik és ötödik beteg}

A rekonstruált aortaszakasz revíziója 2, gyermekkorban operált esetben vált szükségessé a növekedéssel összefüggő testméretváltozás miatt. Az utánkövetés során mindkettőnél az aortitis morfológiai jelei is felismerhetők voltak 4, illetve 10 évvel a primer mútét után. A súlyos intractabilis hypertoniával cardialis decompensatio állapotában operált 6 éves fiú primer beavatkozásként thoracoabdominalis aortoaorticus, ívelt, $8 \mathrm{~mm}$ átmérőjü Dacron bypasson esett át, amelybe mindkét veseartériát beültettük. A látványos korai gyógyulást követően 10 évvel később ismét súlyosbodó hypertonia miatt került vizsgálatra. Hosszmérete $40 \mathrm{~cm}$-rel haladta meg korábbi testmagasságát. A DSA a graft középső szakaszán, a rekesz szintjében súlyos szúkület kialakulását mutatta. Ismételt thoracolaparotomia során a szúkült szakasz Dacron foltplasztikáját végeztük (3. és 11. ábra). A beteg tensiója rendeződött. Jelenleg 20 évvel a második beavatkozás után ép vesefunkció mellett mérsékelt antihipertenzív kezelést igényel és normális életet él.

A másik, 12 éves korában operált fiú aorta angusta miatt került mútétre. A mellkasi és a hasi aorta lumene 3 mm volt korábban. Nem ismert javallat alapján 2 éves isthmicus foltplasztikát kapott. Súlyos hypertonia uralta a klinikai képet. Ívelt, $8 \mathrm{~mm}$-es Dacron grafttal a bal a. subclavia eredésétől az aortabifurcatióra vezetett áthida- 
lásba ültettük be a zsigeri és renalis artériákat (8. és 9. ábra). Zavartalan posztoperatív szak után a gyermek gyors növekedésnek indult. 4 évvel késóbb $55 \mathrm{~cm}$-es hossznövekedést és a hypertonia visszatérését észleltük. A DSA a jobb a. renalis jelentős szúkületét mutatta. Jobb oldali extraperitonealis behatolásból iliorenalis $6 \mathrm{~mm}$-es Gore-tex ${ }^{\circledR}$ bypasst készítettünk. Vérnyomása jelentősen mérséklődött, állapota 17 évvel a második rekonstrukció után stabil.

\section{Hatodik beteg}

22 éves intractabilis hypertonia miatt fiatal katona került kivizsgálásra. A kórkép hátterében az aorta mintegy 5 cm-es szakaszának súlyos szúkülete állt. A jelzett aortaszakasz lumenét Dacron folttal állítottuk helyre. A beteg panaszai megszüntek. A már kamionsoförként dolgozó férfi 34 évvel a fenti beavatkozás után külföldön, vezetés közben hasi fájdalom kíséretében elájult. Azonnal kórházba került, ahol subrenalis hasi aortaaneurysma-rupturát állapítottak meg. Monolimb stentgraft-implantációt és bal-jobb crossover bypasst végeztek. Eseménytelenül gyógyult. A kontroll-CTA a 34 évvel korábban operált thoracoabdominalis aortaszakasz kifogástalan átjárhatóságát mutatta (12. ábra).

\section{Megbeszélés}

A hasi aortacoarctatiót Schlesinger 1835-ben ismertette elsőként, majd Quain 1847-ben közölt hasonló esetet. Power a hasi aortaaplasia részletes leírását 1861-ben tette közzé $[1,2]$. Az első sikeres rekonstruktív beavatkozásról Beattie és mtsai számoltak be 1951-ben [3]. Glenn és mtsai 1952-ben közvetlenül a truncus coeliacus feletti szegmentális coarctatiót splenoaorticus anastomosissal oldották meg [4]. Morris és mtsai 1966-ban 24 esetet találtak az irodalomban, közülük 12 beteg sebészi rekonstrukción esett át. A beavatkozást kilencen élték túl [5]. De Bakey és mtsai 1967-ben már 26 esetben 16 sikeres sebészi helyreállításról tudósítottak [6]. 1971-ben Heberer és mtsai már 180 esetet találtak az irodalomban [7]. Vollmar és mtsai 1973-ig 90 sebészi beavatkozást gyüjtöttek össze az addigi közlemények alapján [8]. Azóta is csak egyes esetek vagy kis szériák ismertetése lelhető fel. Hosszú távú utánkövetésről beszámoló közlemények nagyon ritkák [9-11]. Az atípusos aortacoarctatio előfordulási aránya a típusos coarctatiókhoz viszonyítva 0,5-2\% [11]. Kialakulásában több kóroki tényezőt tételez fel az irodalom. Maycock szerint congenitalis malformatio okozhatja, amelynek hátterében a primitív embrionális kettős dorsalis aorta inkomplett fúziója állhat. A fúzió elmaradása igen ritkán kettős hypoplasticus aorta megmaradását okozhatja [12]. Hasonló morfológiai elváltozásokat okozhat a Takayasu-arteritis, fóként ázsiai populációban fordul elő $[11,13]$. Mások fibromuscularis dysplasiát, posztinfekciós érfali fibrosist, Marfanszindrómát, esetleg Recklinghausen-betegség vascularis manifesztációját, Williams-szindróma részjelenségét vagy autoimmun betegséget tételeznek fel [13-15]. Beteganyagunkban túlnyomóan congenitalis eredetú elváltozás fordult elő, bár a hosszú utánkövetés során négy esetben arteritises késői elváltozásra terelődött figyelmünk más lokalizációjú artériás obliteráció későbbi megjelenése miatt. Egyéb felsorolt patológiai hátteret beteganyagunkban nem észleltünk.

A betegek tüneteit a hypertonia dominálja, ami részben rezisztenciahypertonia az áramlást akadályozó aortastenosis miatt, de jellemző a magas vérnyomás fenntartásában a renin-angiotenzin mechanizmus szerepe [16]. Betegeinkben minél közelebb helyezkedett el az aortastenosis a veseartériák szintjéhez és minél súlyosabb volt az aorta stenosisa, annál inkább játszott szerepet a renovascularis hypertonia a magas vérnyomás fenntartásában. A globális vesefunkció beszúkülése nem jellemző, de a súlyos, intractabilis hypertonia cor bovinumot és cardialis dekompenzációt okozhat, mint néhány esetünkben is megfigyeltük [17]. A mi betegeinknél a postprandialis fájdalom, illetve a dysbasia nem volt jelentős. Több beteg a rekonstrukció után észlelte először az akadálytalan járás élményét, hiszen korábban nem ismerték azt. Az egy betegnél észlelt lábujjgangraena jó járóképesség mellett a carinaszerü coarctatio appozicionális thrombusából származó microembolisatio miatt alakult ki. Túlnyomóan távol-keleti szerzők által észlelt arteritis miatt kezelt esetekben mind az étkezés után jelentkező, mind a dysbasiás panaszok gyakrabban kerültek említésre $[9,11$, $13,15,17]$.

Fizikális vizsgálat során az epigastriumban hallható zörej, a gyengült vagy hiányzó femoralis pulzáció, valamint a felső és alsó végtagok közötti nyomásgradiens volt a legfeltünőbb. Megemlítendő fizikális jel lehet a kitágult, kanyargós intercostalis erek megjelenése (Schwarz-jel), amelyek a szomszédos bordák usuratióját, röntgenfelvételen azok hullámos kontúrját okozhatják (Dock-jel). A laboratóriumi vizsgálatok a sebészi beavatkozás előtt nem utaltak gyulladásos aktivitásra, de 4 betegünk a morfológiai kép alapján szteroidkezelést kapott.

A diagnosztika alapját korábban a DSA, az utóbbi 2 évtizedben a CTA adta. Az általunk észlelt morfológiai változatokat a 2. táblázatban foglaltuk össze. Az irodalmi adatok is a kórkép számos morfológiai változatáról számolnak be $[10,17]$. Az elváltozások egyedi - túlnyomóan sebészi - megoldásokat tesznek szükségessé, bár az utóbbi időben endovascularis kezelésról is tudósítanak $[9,11,13,17,18-20]$.

A megoldások javallata számos szempont alapján határozható meg:

1. Klinikai tünetek súlyossága, hypertonia kezelhetősége.

2. Életkor, testméretek.

3. Az aortacoarctatio elhelyezkedése, kiterjedése, a szűkület mértéke.

4. Arteritisre utaló klinikai és laboratóriumi jelek jelenléte.

5. Kollaterális hálózat fejlettsége.

6. A szúküilt aortaszakasz kalcifikációja. 
Atípusos aortacoarctatio miatt csecsemőkorú beteg nem került mütétre.

A típusos aortacoarctatio az esetek túlnyomó többségében a születés után röviddel felismerésre és megoldásra kerül. Az atípusos coarctatio - mint eseteink kormegoszlása bizonyítja - csak jelentős késéssel kerül látótérbe. Ennek oka a szokatlan elhelyezkedésen és ritka előforduláson túl a kevésbé drámai és ezért később felismert klinikai tünetekben rejlik.

A testméretek jelentőségét betegeink kormegoszlása illusztrálja. 16 éves kor alatt 12 beteget operáltunk, akik között csak két 10 év alatti gyermek volt, a többiek nem végleges testmérettel, de serdülőkorban kerültek mútétre. Két beteg évekkel később a növekedés okozta méretváltozások miatt ismételt sebészi beavatkozásra szorult, bizonyítva a növekedés, a testméretek szerepét a megfelelő javallat és megoldás kialakításában. 2 betegnél a hypertonia kezelése és a vesefunkció folyamatos ellenőrzése mellett a hosszú szakaszt érintő coarctatio halasztott áthidalását tartottuk indokoltnak azért, hogy a növekedés előrehaladtával minél inkább végleges testméretek mellett tartós megoldást adjunk megfelelő méretü graft beültetésével. 4 betegben foltplasztikával oldottuk meg az aorta szúkületét, egy betegben a foltot a bal a. renalis rövid fötörzsére kiterjesztve, annak aneurysmaticus elváltozását is megoperáltuk. Növekedés okozta későbbi beavatkozásokra az irodalomban szerény utalásokat találunk. Stanley és mtsai 53 beteg esetét feldolgozó közleménye utal a későbbi revízió szükségességére $[18,19]$.

A gyermekkorban operált betegek közül 3 esetben merült fel arteritis lehetősége kizárólag a morfológiai kép alapján. Laboratóriumi paraméterek aktív lobos folyamatot egyik esetben sem igazoltak, de átmeneti szteroidkezelést kaptak.

A 16 éves kor után operált 15 betegünk testmérete megközelítette, illetve elérte a végleges állapotot, így náluk hosszú távú eredményt biztosító primer megoldást választhattunk. Ebben a betegcsoportban arteritis 4 esetben merült fel a diagnózis és a beavatkozás időpontjában a morfológiai elváltozások alapján. Évekkel később 2 nőbetegnél jelentkező supraaorticus arteria obliteratio, illetve egyiküknél tartós dialízist igénylő renovascularis insufficientia utalt Takayasu-betegség lehetőségére. Gyermekkorban operált 2 fiúnál évekkel később ugyancsak jelentkeztek aortitisre utaló morfológiai elváltozások. Tapasztalataink nem adtak választ arra, hogy az aortitis primer vagy szekunder módon járul hozzá e ritka kórkép kialakulásához.

A számos variációjú atípusos coarctatio egyedi megoldások széles spektrumát teszi szükségessé. A rövid szakaszú elváltozások foltplasztikával eredményesen kezelhetők. Egyes esetekben körkörös kalcifikáció ennek a megoldásnak nem nyújt teret. A nem teljes körfogatot érintő meszesedés mellett a foltplasztika elvégezhető és megkíméli a kollaterális keringést is. Bár néhány közlemény a foltplasztika késői szövődményeit, például álane- urysma-képződést, restenosist említ [11, 13, 17, 18]. Saját anyagunkban álaneurysma-képződéssel atípusos aortacoarctatio sebészi megoldása után nem találkoztunk. Restenosis egy esetben a thoracoabdominalis grafton, a rekesz szintjében, egy esetben a jobb a. renalison alakult ki.

Az aortaívet érintő atípusos coarctatiók egy része foltplasztikával megoldható, de hosszabb szakaszon jelentkező elváltozás aorta ascendens és descendens közötti áthidalással oldható meg [20-22]. A bypassmegoldás elönyei:

- megkíméli a kialakult kollaterális keringést,

- elkerüli az esetenként súlyosan kalcifikált stenoticus aortaszakaszt,

- az anastomosisok ép szakaszokon tangenciális kirekesztésben elkészíthetők,

- ívelt graft alkalmazásával teret ad a növekedés számára,

- az áthidalás egyénenként változó hosszúságban alkalmazható,

- megfelelő graftméret hosszú távú jó eredményt ad,

- a graftba direkt vagy indirekt módon a nagy mellékágak beültethetók.

A graftinterpositum, véleményünk szerint, kevésbé előnyös megoldás, mert az aorta érintett szakaszának teljes kirekesztésével jár és részben kiiktatja a kollaterális keringést. A kalcifikáció technikai nehézséget okozhat és nem ad lehetőséget a növekedés okozta változásoknak, mint azt egy nőbetegünknél tapasztaltuk [23].

Az utóbbi időben egyes közlemények az atípusos aortacoarctatio endovascularis kezelésével szerzett szaporodó tapasztalatokról tudósítanak $[24,25]$. Az endovascularis megoldások az érintett aortaszakaszon az érfali szerkezet rugalmatlansága miatt a hosszanti berepedés veszélyével járhat, körkörös kalcifikáció esetében aligha elvégezhető. Stent behelyezése gyermekkorban az adott átmérő miatt csak időleges megoldást jelenthet. A lobos érfolyamat fellángolása a tágítás tartós eredményét teheti tönkre. Ilyen esetekben távoli ép aortaszakaszok között létesített múanyag érrel való áthidalását tartják a kedvezőbb megoldásnak [11, 13, 23, 24].

Dolgozatunkban az atípusos aortacoarctatio sebészi kezelésével szerzett tapasztalatainkat foglaltuk össze. A sebészi megoldások hosszú távú eredményeit több mint 3 évtizedes utánkövetés alapján mutattuk be. A választott megoldások betegeink túlélési esélyeit jelentősen javították, bár késői szövődmények is kialakultak, amelyeket újabb beavatkozással betegeink túlnyomó többségében sikerrel oldottunk meg. A szövődményeket a növekedéssel kapcsolatos testméretváltozások vagy aortitis késői relapsusa, illetve megjelenése okozta. Az aortitis megelőzése, illetve az aktív folyamat felismerése, megfelelő gyógyszeres kezelés beállítása jelentős mértékben hozzájárulhat a sebészi, illetve endovascularis kezelési módszerek tartós eredményeinek fenntartásához [13, $26,27]$. 
Anyagi támogatás: A cikk megírása anyagi támogatásban nem részesült.

Szerzői munkamegosztás: D. Cs.: A kézirat megszövegezése, ellenőrző vizsgálatok, beteganyag gyújtése. E. L., B. P., V. G., B. L.: Konzultáció. N. G.: Beteganyag feldolgozása. Ny. G.: A dolgozat szerkesztése. A cikk végleges változatát valamennyi szerző elolvasta és jóváhagyta.

Érdekeltségek: A szerzőknek nincsenek érdekeltségeik.

\section{Irodalom}

[1] Heberer, G., Rau, G., Schoop, W.: Kongenitale Arterielle Krankheiten in Angiologie. Thieme, Stuttgart, 1974.

[2] Vollmar, J.: Die rekonstruktive Chirurgie der Arterien. Thieme, Stuttgart, 1975

[3] Beattie, E. J. Jr., Cooke, F. N., Paul, J. S., et al.: Coarctation of the aorta at the level of the diaphragm treated successfully with preserved human blood vessel graft. J. Thorac. Surg., 1951, 21(5), 506-512.

[4] Glenn, F., Keefer, E. B, Speer, D. S., et al.: Coarctation of the lower thoracic aorta immediately proximal to the celiac axis. Surg. Gynecol. Obstet., 1952, 94(5), 561-569.

[5] Morris, G. C. Jr., De Bakey, M. E., Crawford, E. S., et al.: Late results of surgical treatment of renovascular hypertension. Surg. Gynecol. Obstet., 1966, 122(6), 1255-1261.

[6] De Bakey, M. E., Garret, H. E., Howell, J. F., et al.: Coarctation of the abdominal aorta with renal arterial stenosis: surgical consideration. Ann. Surg., 1967, 165(5), 830-843.

[7] Heberer, G., Zumtobel, V., Eigler, F. W., et al.: Treatment of atypical suprarenal stenoses of the aorta in hypertensives. Dtsch. Med. Wochenschr., 1971, 96(15), 615-620.

[8] Vollmar, J., Voss, E. U., Nadjafi, A. S., et al.: Die atypische coarctatio aortae. Thoraxchir. Vask. Chir., 1976, 24(2), 107-118.

[9] Wada, J., Kazui, T.: Long-term results of thoracoabdominal bypass graft for atypical coarctation of the aorta. World J. Surg., 1978, 2(6), 891-896.

[10] Mickley, V., Fleiter, T.: Coarctations of descending and abdominal aorta: Long-term results of surgical therapy. J. Vasc. Surg., $1998,28(2), 206-214$

[11] Taketani, T., Miyata, T., Morota, T., et al.: Surgical treatment of atypical aortic coarctation complicating Takayasu's arteritis - experience with 33 cases over 44 years. J. Vasc. Surg., 2005, 4l(4), $597-601$

[12] Maycock, W. A.: Congenital stenosis of the abdominal aorta. Am. Heart J., 1937, 13(6), 633-646.

[13] Ogino, H., Matsuda, H., Minatoya, K., et al.: Overiew of late outcome of medical and surgical treatment of Takayasu arteritis. Circulation, 2008, 118(25), 2738-2747.
[14] Janzen, J., Vuong, P. N., Rothenberger-Janzen, K.: Takayasu's arteritis and fibromuscular dysplasia as causes of acquired atypical coarcation of the aorta: retrospective analysis of seven cases. Heart Vessels, 1999, 14(6), 277-282.

[15] Kimura, M., Kakizaki, S., Kawano, K., et al.: Neurofibromatosis type 1 complicated by atypical coarctation of the thoracic aorta. Case Rep. Pediatr., 2013, 2013, Article ID 458543.

[16] Alpert, B. S., Bain, H. H., Balfe, J. W., et al.: Role of renin-angiotensin-aldosterone sytem in hypertensive children with coarctation of the aorta. Am. J. Cardiol., 1979, 43(4), 828-834.

[17] Dzsinich, Cs., Jarányi, Zs., Sepa, Gy., et al.: Atypical thoracoabdominal aortic coarctation in cardio-aortic and aortic surgery. In: Kawada, S., Ueda, T., Shimizu, H. (eds.): Cardio-aortic and aortic surgery. Springer Verlag, Tokyo, 2001.

[18] Stanley, J. C., Criado, E., Eliason, J. L., et al.: Abdominal aortic coarctation: Surgical treatment of 53 patients with thoracoabdominal bypass, patch aortoplasty or iterposition aortoaortic graft. J. Vasc. Surg., 2008, 48(5), 1073-1082.

[19] Go, M. R., Bhende, S., Smead, W. L., et al.: Long-term complications in two patients after aortoaortic bypass for midaortic syndrome. Ann. Vasc. Surg., 2013, 27(4), 499e9-499e12.

[20] Robicsek, F., Hess, P. J., Vajtai, P.: Ascending distal abdominal aorta bypass for treatment of hypoplastic aortic arch and atypical coartation in the adult. Ann. Thorac. Surg., 1984, 37(3), 261263.

[21] Shimada, N., Tanaka, M., Katayama, I., et al.: Ascending aortaabdominal aorta bypass for atypical coarctation with intractable hypertension due to aortitis syndrome; report of a case. Kyobu Geka, 2014, 67(3), 239-242.

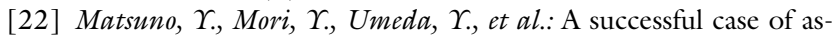
cending aorta-abdominal aorta bypass for middle aortic syndrome. Vasc. Endovascular. Surg., 2009, 43(1), 96-99.

[23] Dzsinich, Cs., Vaszily, M., Vallus, G., et al.: Late complictions and treatment options of aortic coarctation operated in childhood. [Gyermekkorban operált aortacoarctatiók késői szövődményei és ellátásuk.] Orv. Hetil., 2014, 155(30), 1189-1195. [Hungarian]

[24] Delis, K. T., Gloviczki, P.: Middle aortic syndrome: from presentation to contemporary surgical and endovascular treatment. Perspect. Vasc. Surg. Endovasc. Ther., 2005, 17(3), 187-203.

[25] Keith, D. S., Markey, B., Schiedler, M.: Successful long-term stenting of an atypical descending aortic coarctation. J. Vasc. Surg., 2002, 35(1), 166-167.

[26] Isobe, M.: Takayasu arteritis revisited: Current diagnosis and treatment. Int. J. Cardiol., 2013, 168(1), 3-10.

[27] Ohigashi, H., Haraguchi, G., Konishi, M., et al.: Improved prognosis of Takayasu arteritis over the past deacade - comprehensive analysis of 106 patients. Circ. J., 2012, 76(4), 1004-1011.

(Dzsinich Csaba dr., Budapest, Róbert Károly krt. 44., 1134 e-mail: escvs@medical.hu) 